\title{
Unravelling processes of alliance capability development: Longitudinal processual insights from an emerging country multinational enterprise
}

\begin{abstract}
Purpose: The purpose of the paper is to explore and unbundle the complex processes underpinning development of alliance capabilities, particularly in the context of emerging country multinational enterprises. More specifically this paper focuses on how firms internalize and translate knowledge generated from experiences gained by participating in international collaborations.
\end{abstract}

Design / methodology/approach: We adopt an exploratory case study approach to undertake in-depth processual analysis of alliance capability development in an Indian biopharmaceutical company. We focused our analysis on the initial four international alliances the company formed and identified key elements pertaining to alliance capabilities that the company internalized and those that it could not, as this was key in understanding alliance capability.

Findings: Our research show that based on experiences from previous alliances, the Indian organization was able to overhaul its negotiation and governance designing processes and practices and also made robust changes to its internal communication and coordination practices. Interestingly, the organization, however, did not make any significant changes to its processes and practices regarding partner selection.

Practical implications: The results from our study can be used by managers to develop processes and practices when it comes to developing alliance capabilities.

Originality / value: The paper is novel as it addresses two specific gaps in the nascent alliance capability literature. First, it provides insights on how different constituent elements / aspects of alliance capability actually develop and integrate within organizational system over time and in the process the paper identifies that some aspects are better internalized as compared to other aspects. Second, by focusing our attention on an Indian biopharmaceutical company, we attempt to address a gap in to alliance capability research, which has neglected emerging country multinational entities. 
Key words: International Strategic Alliances; Alliance Capability Development; Emerging Country MNEs; Processual approach; Longitudinal Case Study Research. 


\section{INTRODUCTION:}

Alliance capabilities are considered as a source of competitive advantage (Ireland et al., 2000; Kale et al., 2002) and yet, not much is known on how organizations develop their alliance capability, which thus remains a black box (Kaupilla, 2015). Research on alliance capability has followed two distinct yet overlapping streams (see for e.g. Schreiner et al., 2009; Wang, and Rajagopalan, 2015; Kohtamäki et al., 2018). Whereas the first stream explores the development of alliance capability by identifying approaches and mechanisms firms adopt in cultivating and enhancing their ability to manage alliances (e.g. Anand and Khanna, 2000; Kale et al., 2002; Kale and Singh, 2007; Schlike 2010), the second stream aims to identify and examine different elements or aspects that constitute a firm's alliance capability (e.g. Dyer and Singh, 1998; Kale and Singh, 2009). These two streams of research, however, attract two distinct literature gaps. First, they offer limited insights into how different constituent elements of alliance capability actually develop and integrate over time, as a firm translates its experiences in one or more alliances into an encompassing 'alliance-capability' (Schreiner et al., 2009; Kale and Zollo, 2005; Heimeriks and Duysters, 2007). Second, majority of studies have explored this phenomenon in larger and more established companies, predominantly based in the US and Europe - hence the need for investigating the phenomenon in organizations located in emerging economies, particularly in the backdrop of increasing international alliancing activities of emerging country multinational entities (EMNEs). Recent studies such as Chand and Katou (2012) - in an Indian context and Ahlstromet al (2014) - in a Chinese context have investigated some aspects relating to this topic, particularly focusing on determinants for partner selection, there is a need for further investigation of the processes underpinning alliance activities in general and management of international strategic alliances in particular by EMNEs (Pereira, Patnaik, Temouri, Tarba, Malik, Bustinza, 2019). This paper aims to address these two gaps in the alliance capability literature.

More specifically, we address the first gap by adopting a longitudinal processual approach (Pettigrew, 1997) to explore nuances underpinning development of alliance capabilities. In order to gain a granular in-depth and critical understanding of the development of alliance capabilities in firms from emerging economies we chose to focus on - Indo-Bio, a rapidly growing emerging economy (Indian) bio-pharmaceutical firm (hereafter referred to as Indo-Bio in this paper). In doing so, we address the second gap in the extant alliance capability 
literature, i.e., of investigating the phenomenon (development of alliance capabilities) in an EMNE.

The remainder of this paper is structured as follows. We start by providing a review of key literature on alliance capability. Thereafter we describe the research design detailing how we collected and analyzed the data. We follow this with a description and discussion of findings pertaining to development of alliance capability in Indo-Bio. We conclude with an overview of the implications of our finding for future research on alliance capability and managerial practice.

\section{Literature Review and research questions}

\subsection{Alliance Capability}

Alliance capability is conceptualized as a firm-specific capability that enhances its ability to form, organize and manage alliances, and which develops through effectively capturing, sharing and disseminating alliance management know-how associated with prior experience (Kale and Singh, 2007). Scholars studying alliance capabilities draw on theoretical insights from organizational learning and dynamic capabilities literature and posit that firms develop alliance capabilities by accumulating, integrating, and internalizing knowledge and skills gained by participating in different alliances with various partners and modifying these as situations evolve (Anand and Khanna, 2000). This perspective is also consistent with conceptualization of organizational capabilities as embedded in activities and routines within firms for addressing complex, practical and repeated problems (Gulati et al., 2009). Extant studies suggest that firms possessing such capabilities attain greater success in their alliancing activities (Dyer and Singh, 1998; Kale and Singh, 2007; Heimeriks and Duysters, 2007). In this regards, Anand and Khanna (2000) were amongst the first to study the relationship between alliance experience and alliance performance. They observed that when firms with prior alliance experience announced formation of new alliances the stock market reacted favorably, apparently accepting alliance experience as a proxy for alliance capability. Other scholars have, however, considered alliance experience as an antecedent for the development of alliance capability, arguing that the experience gained by participating in repeated alliancing activities with either one or multiple partners enable organizations to create routines and develop policies and procedures to effectively undertake alliance-specific activities (Gulati et al., 2009). Zollo 
et al (2002) in their research on biotechnology companies found that repeated alliances with the same partner enable development of partner- specific routines, which they conclude enhances performance of subsequent alliances involving the same partners.

Extant research suggests that alliance experience also contribute in creation of 'alliance management function' particularly in larger well-established firms (Kale and Singh, 2007; Heimeriks and Duysters, 2007; Schreiner et al., 2009). Kale et al. (2002) define alliance management function as "a separate dedicated organizational unit/team charged with the responsibility to capture prior alliance experiences" (p.750). This structural entity plays a critical role in organizing and coordinating activities related to alliance formation, institutionalizes alliance development processes and systems, and ultimately facilitates and enhances the development of alliance capability. Firms with these units appear to manage their alliances more successfully than those that do not have these dedicated teams (Kale et al., 2002; Kale and Singh, 2009). The Office of Alliance Management (OAM) of pharmaceutical giant Eli Lilly is often cited as an illustration of the alliance management function (see Kale and Singh, 2007).

\section{2: Stages in alliance development and constituent elements of alliance capability}

Extant research suggest that strategic alliances develop and evolve over time and in that context, alliance process research specifically pays attention to the processes underpinning formation, development and dissolution of strategic alliances (Ring and Van de Ven, 1994; Doz, 1996; de Rond and Bouchikhi, 2004; Salk, 2006). Alliance process scholars concur that overlapping phases of formation, operation and outcome / evaluation phases underpin the alliance life cycle (Das and Teng, 2002; Wang and Rajagopalan, 2015; Berends and Sydow, 2020; Patnaik, 2011; Patnaik, Pereira, Temouri, Malik and Roohanifar, 2020). Figure 1 provides an overview of main phases in alliance life cycle and the key activities and aspects that comprise the phases.

Please insert Fig 1 over here

Studies on constituent elements of alliance capability seek to identify distinct skills and competences that firms require to undertake various tasks during different phases of alliance development (Kale and Singh, 2009). Building upon insights from existing alliance process or alliance development literature, Schreiner et al. (2009) identified coordination, communication 
and bonding (inter-personal relationship) as critical to the development of alliance capability while Altinay et al., (2014b) found communication plays a central role in development of trust and relationships in franchisees a form of alliances

\subsubsection{Alliance Formation Phase}

Shah and Swaminathan (2008) identified partner complementarity, partner commitment and partner compatibility as three most influential aspects pertaining to partner selection. Whereas complementarity refers to the extent to which partners contribute non-overlapping resources, compatibility pertains to the degree of similarity in cultural orientation of the partners and commitment entails willingness of partners to fully commit to their participation in the alliance (Beamish et al., 2016). As such, commitment is an important factor in developing partner relationships (Altinay and Brookes, 2012; Altinay et al., 2014a). In the study of "franchisees' perceptions of relationship development in franchise partnerships" in the context of Turkish and Chinese franchisees, Altinay et al. (2014a) found that trust and commitment play a significant part in formation phase of partnerships.

The alliance formation phase also involves designing and negotiating appropriate governance structures. Governance structures not only reflect the nature and scope of the relationship between the partners but also specify their resource commitment and operational responsibilities (Hennart, 2005). Governance structures are generally contract or equity based. When objectives are not specific or difficult to specify in advance, contractual strategic alliances are created. Contracts generally take one of two forms: (1) explicit in which various contingencies and modes of resolution spelt out in advance or (2) implicit/relational in which parties accept that as their alliance develops, the contract will require adjustments. While implicit contracts provide more flexibility, they are also more prone to conflicts over relative contributions to value creation and value capture. Given this trend, different scholars (for e.g. Lumineau et al., 2011) have called for developing a better understanding of contractual provisions in alliance agreements. In this backdrop, Manzini and Mariotti (2005)'s work on negotiations in alliance context assumes significance. They sensitize us to the nuances underpinning negotiation process, particularly emphasizing that negotiations in such arrangements often do not occur between individuals but among groups with each representing 
composite interests and whose behaviour are also underpinned by some collective decision mechanism.

\subsubsection{Post-Alliance Formation Phase}

The post-formation phase entails coordination of tasks and management of inter-organizational and inter-personal relationships based on open communication, reciprocity and collegiality amongst actors directly involved in the alliance (Doz, 1996). Schreiner et al. (2009) note that three aspects underpinning alliance capability, namely: (a) coordination; (b) communication and; (c) and bonding, - all play critical role in the functioning of alliances. In this regard, prior alliance experience not only contributes to the development of firm specific routines and other structural elements to organize and coordinate tasks but also facilitates interactions between managers at operational and strategic levels, enhancing communication and bonding skills of individual alliance managers (also see for instance Altinay et al., 2014a; Altinay and Brookes, 2012; Heimeriks and Duysters, 2007).

Although extant studies have attributed alliance experience as a key mediator in the development of alliance capability, fewer studies have attempted to illuminate how firms actually learn from participating in alliances and how they internalize learning within their respective organizational systems. Similarly, few studies have attempted to capture the processes and activities, and development of relationship building skillsets of individual alliance managers through participation in different alliances (Kale and Singh, 2009; Schreiner et al, 2009). The significance of our research is, thus two fold. First, we seek to address the above shortcomings in the extant alliance capability literature and second, we do so by 
examining development of alliance capability in an EMNE, in this instance, one of the fastest growing biopharmaceutical company in India. Thus, our key research questions are as follows:

RQ1. How do EMNEs develop their alliance capability?

SubRQ1. How do EMNEs develop their alliance formation capabilities?

SubRQ2. How do EMNEs develop their post-formation alliance capabilities?

Based on the above research questions, we reiterate that the overarching objective of this research is to identify and examine how different constituent elements / aspects of alliance capability actually develop and integrate within organizational system over time.

\section{METHODLOGY}

Given the exploratory nature of our research question and the sub-questions, we used Yin's (2017) case study methodology. Majority of studies on alliance capability have adopted large cross-sectional research designs using secondary sources of data (Kohtamaki et al., 2018; Wang and Rajagopalan, 2015). Within the broader field of alliance research, such research designs and methodologies are criticized for providing 'acontextual' and 'ahistorical' picture of alliance phenomenon (see Parkhe, 2006; Bell et al., 2006). To rectify this lacuna, alliance scholars have called to embrace 'processual approach' to critically examine issues pertaining to the alliance phenomenon (Contractor, 2005; Parkhe, 2006; Patnaik, 2011; Pereira, Temouri, Patnaik, Mellahai, 2020). Process, as a method of analysis, is often utilised in three ways (Pettigrew, 1997). The first, as a logic that aids in describing a causal relationship in a variance theory. Second, as a categorisation of thematic areas or concepts that has reference to activities at different levels such as at individual or organisational level. Third, as an evolution and iteration leading to a sequence of events that explains and portrays change over time. Pettigrew, (1997: 338) contends that 'only the third approach explicitly and directly observes the process in action' and hence 'process' here is taken to mean 'a sequence of individual and collective events, actions and activities unfolding over time in context'. Qualitative methods are best suited for processual studies (Pettigrew, 1997) particularly when the research entails "opening the black box of organisational processes, the 'how', 'who' and 'why' of individual and collective organized action as it unfolds over time in context" (Doz, 2011: 583). Notwithstanding limitations associated with case study research, particularly pertaining to generalization and replicability, adopting a case studies approach is valuable to gain gaining 
an in-depth understanding of complex phenomena, such as alliance capabilities. In this respect there has been greater call from scholars who specifically focus on alliance capability phenomenon to undertake longitudinal case study research (see for instance Wang and Rajagopalan, 2015; Kohtamaki et al., 2018). Our focal organization, Indo-Bio, one of the fastest growing biopharmaceutical companies from the emerging economies is an appropriate site to undertake this research for two reasons. First, not until mid-1990s, the company did not have any focus or presence in bio-pharmaceutical sector and it did so to leverage its biotechnology process and fermentation capabilities; and second, not until 2003, it had formed a strategic alliance with any international partner. Interestingly, it entered four strategic alliances between 2003 and 2008, and these four alliances are focus of our attention in the paper to investigate development of alliance capability in this Indian company. The case study offers us a unique opportunity to capture learning and institutionalization of capabilities between the period when the initial three alliances were formed (2003-04) and how some of the practices were adopted as it formed its alliance with the forth partner in 2008.

Our data collection approach was underpinned by our overarching research objective and the research questions. Therefore, we focused our attention to develop a better understanding of (a) how did Indo-Bio undertook partner selection and negotiated the governance mechanisms; (b) how did Indo-Bio coordinate and communicate internally with its own organizational members and externally with the respective alliance partners; and (c) how it internalized learning from alliance experiences of within its structures and processes. Our aim is consistent with the view that organizational capabilities are a time-based concept and result from an evolutionary process (Niesten and Jolink, 2015). Our research used several data sources to document the development of specific elements of alliance capability. These include: (a) qualitative data generated from semi-structured interviews with key personnel, particularly in Indo-Bio's R\&D division, involved in alliances, and (b) archival data including corporate documents, press releases, annual reports and other investor presentations. The archival documents were particularly helpful in tracing the historical evolution of the company, the vision it set out for itself after decided to become a bio-pharmaceutical company in mid 1990s and how forming strategic alliances with international partners was a key element of the 
company's overarching strategy. Thus, information gathered through archival documents was also used to complement information garnered through the semi-interviews.

(Please insert Figure 2 over here).

(Please insert Figure 3 over here)

We focused on the R\&D division as this division initiated, organized and managed the alliances. In total, we interviewed eight senior managers multiple times over 15 months' period. Amongst the eight mangers were individuals who were directly involved in negotiating the governance mechanisms for the four alliances and who were members of the alliance management team (AMT). Table 1 lists the details of the respondents.

(Please insert Table 1 over here)

Consistent with Eisenhardt and Graebner (2007) and Yin (2017), we adopted the standard procedure of case study research and we first developed case histories of Indo-Bio's first four major strategic alliances. These histories described the chronology of the events that shaped the evolution of each of the four initial alliances, which provide the basis for our study. Table 2 provides a brief description of Indo-Bio's four alliances.

(Please insert Exhibit 1 here)

Following Corley and Gioia (2004) and Altiany et al., (2014c) we adopted three step approach to analyze our interview transcripts from raw data to the outcome. First, from the interview, transcripts we identified and categorized all information pertaining to activities all the four alliances Indo-Bio. We organized the information under two broad categories, namely (a) why and how Indo-Bio formed strategic alliances with the respective four partners (alliance formation capabilities); and (b) how did Indo-Bio manage strategic and operational issues pertaining to each individual alliances after they were formed after the alliances were formed (post-formation capabilities). As a second step, the first-order concepts derived from the two broad categories were linked to second-order themes, namely (a) processes and practices and actors involved in different activities relating to alliance formation; and (b) coordinational and 
communication processes and key actors involved in overseeing strategic and operational aspects after the alliance has been formed. In this context, we identified souring of relationship with US Bio1 in 2008 as a key event and it provided an opportunity to the Senior Managers in Indo-Bio to evaluate its structure processes and practices on all aspects relating to alliance management. This reflective period, resulted in specific and significant changes, particularly how the company negotiate and design contractual agreements as well as how the company coordinate and communicate internally, with other organizational members, and externally with members of the partner organizations. As a final step, we captured the resulting changes and linked them to (a) alliance formation capability; and (b) post formation alliance capabilities. We have conceptualized both (a) and (b) as aggregated dimensions of alliance capability. Figure 4 illustrates the final data structure and it summarises the first order constructs and second order themes (structures, processes and mechanisms) and linking them to alliance capability (aggregated dimensions).

Please insert Figure 4 over here

\section{FINDINGS}

Following Kale and Singh (2009), Schreiner et al. (2009), and Kohtamaki et al (2018), we focused on the distinct capabilities that underpin different stages of alliance development. These capabilities pertain to: (a) partner selection, (b) negotiating and designing the governance structure and (c) post-formation alliance management. The findings from our analysis helped us to unravel in which areas Indo-Bio, learning from experience, succeeded in developing structures and processes underpinning its overall alliance capability. We also unearth the area it did not succeed to develop any distinct capability.

\subsection{Alliance formation capability}

\subsubsection{Partner selection capability}

Extant studies highlight the importance of assessing and selecting appropriate partners to increase the likelihood of effective functioning and survival (Geringer, 1991; Dacin et al., 1997; Shah and Swaminathan, 2008; Cummings and Holmberg, 2012). Hence, the ability to identify, vet and assess potential partners, and undertake robust negotiation to form alliances is a critical element of alliance capability. Partner selection involve two key considerations: (1) pertaining to task, i.e. complementarities such as products, skills or resources possessed by the 
potential partner and (2) pertaining to partner characteristics, i.e. strategic and cultural compatibility, reputation and commitment to alliance goals, knowledge transfers between partners and objectives (Shah and Swaminathan, 2008; Beamish et al., 2016; Brooke and Altinay, 2017; ).

Task complementarities are of particular significance in biopharmaceutical industry as development of new drugs result from collaborative endeavors amongst partners who possess specific expertise to facilitate necessary upstream or downstream activities (Powell et al., 1996). The expertise of Indian biopharmaceutical firms to undertake downstream activities, particularly those related to process development and manufacturing, have been well documented (cf. Athreye et al. 2009; Chittoor et al. 2009). Simultaneously, it is also noted that Indian pharmaceutical firms lack sufficient capabilities to undertake upstream activities to discover new molecules. In this context Indo-Bio was no exception and to exploit its downstream expertise it "actively pursued forming partnerships to co-develop new products" (Head of R\&D). The company managers emphasized that Indo-Bio has historically aspired to become "partner of choice" for small research driven biotechnology firms. In exchange, IndoBio offered its expertise in developing processes to manufacture new drugs, undertake clinical trials and even market new biopharmaceutical products in India, a rapidly developing market for drugs.

To capture the development of alliance formation capability in Indo-Bio, we explored: (a) partner selection criteria Indo-Bio adopted in evaluating potential partners and (b) unfolding of the processes pertaining to partner selection, negotiation of the governance mechanism and drafting of the contractual provisions. Despite Indo-Bio's avowed objective of 'actively pursuing partners' our study indicated that its four alliances were formed opportunistically, i.e. "happened by chance" (Head of R\&D) and the partnerships were established with those "whose technology was perceived to be useful at that point" (Senior Project Manager 2). For instance, Indo-Bio entered into alliance with Socialist-Bio when Indo-Bio's CEO visited the home country of Socialist-Bio as part of a trade delegation. Similarly, the alliance with USBio1 came about following an informal enquiry from the CEO of US Bio 1. We noted a similar partner selection pattern with respect to selection and formation of Indo-Bio's alliances with US-Bio2 for the development of oral insulin and with US-Bio3 to develop novel oncology biopharmaceutical drugs. Thus, given the opportunistic nature of alliance formation, perceived partner complementarity rather than partner compatibility or commitment was the predominant partner selection criterion adopted by Indo-Bio. 
Two factors underpinned the emphasis on complementarity. First, Indo-Bio aspired to become a fully integrated global biopharmaceutical company and central to attain this objective was to become "a product centric and not just a service centric company" (Senior Project Manager 2). However, as it lacked expertise/capability in discovering new molecules, it deliberately chose to establish partnerships with firms that possessed upstream (discovery) capabilities but lacked downstream (developmental) capabilities. While the partnership with Socialist-Bio introduced Indo-Bio to a new area of drug discovery-- monoclonal antibodies - it did little to expand Indo Bio's drug development capabilities. However, it gave the company greater confidence to collaborate with other companies, such as US Bio 1, who were using the same technology. In 2006, the alliance between Indo-Bio and Socialist-Bio yielded fruit in the form a bio cancer drug MonoBioInd. However, this success did not significantly enhance IndoBio's reputation to attract reputable established drug discovery partners, which was aptly highlighted by the company's R\&D Head, who said, “We struggle to attract partners with a first class molecule; rather, we essentially attract those who we call as from the left over group..." This situation, provides an insight on why partner compatibility and partner commitment were not high on the agenda in selecting new partners.

Closer analysis of alliance processes in Indo-Bio reveals the central role of the CEO. Our respondents credited the CEO for successfully leading the transformation of Indo-Bio from manufacturer of enzymes to a biopharmaceutical company. They specifically acknowledged CEO's role in setting the vision for the company and taking key decisions on specific product categories and partnerships. Interestingly, the R\&D Head attributed some of these decisions to be based on 'gut feeling' and in this respect particularly cities the example of the alliance with Socialist-Bio. Interestingly until the alliance came about, Indo-Bio did not specialize in monoclonal antibodies and lacked expertise in handing them. The CEO was instrumental in the formation of Indo-Bio's alliances with US Bio2 and US Bio 3. We derive two conclusions from these observations. First, perceived complementarities underpin the primary consideration for partner selection; and second, the CEO's acted as the central actor in the partner selection process and in that respect the perception of the CEO on complementarities received greater prominence.

\subsubsection{Capabilities to negotiate and design governance structure}

The choice of appropriate formal and informal alliance structures (Gulati and Singh, 1998; Hennart, 2006) as well as contractual provisions (Argyres and Mayer, 2007) influence effective 
functioning of an alliance. Therefore, the ability of partners to negotiate and design an effective formal as well as informal alliance structure is considered as a critical element of firms' overall alliance capability (Kale and Singh, 2009; Schreiner et al., 2009).

In our analysis, we found the collapse of Indo- Bio's relationship with US Bio1 four years after the alliance as a critical event from Indo-Bio's standpoint. We identified two incidents that triggered the breakdown of that relationship. First, contrary to contractual terms, US Bio 1 could only discover two out of four potential human antibody molecules. Two years after the discovery of the molecules, Indo-Bio's project team found that one of the two molecules, IUSA1, was structurally defective and deemed it "not worth developing further due to increased uncertainty around its functionality and the cost of development" (Senior Project Manager 2). US Biol acknowledged the structural aberration of the molecule but disagreed with the assertion that the molecule could not be developed and was reluctant to bear the additional cost to develop the molecule. The second incident pertained to inclusion of a clause in the final contract agreement, which Indo-Bio perceived to be contrary to what it had agreed to. According to the erstwhile R\&D Head, “... from the beginning I had insisted that we would have the manufacturing rights. Wherever the drugs are sold we will be the manufacturer and hence the sole supplier. Only the revenue from the sale of products was to be shared between us...not the profits from manufacturing.... “. In other words, from India-Bio's point of view, the final contractual agreement was favourable to US Bio 1 at its expense and more importantly, Indo-Bio came to know about the clause only after US Bio refused to bear the cost for developing the defective molecule. These two incidents influenced Indo-Bio's decision to terminate further development of IUSA1 molecule as well as downgrading of the relationship with US Bio1. Subsequently the relationship between the two partners terminated in 2010.

Learning from this experience, Indo-Bio's Senior Management Committee (SMC) suggested three specific structural and procedural changes. They were; (a) the R\&D department will continue to drive the alliance formation process but in close interaction with the legal department, which previously had very limited involvement; (b) draft of any contractual agreement pertaining to any new alliance will be approved by the SMC; and (c) creation of an expert group comprising members from various departments to undertake partner-specific due diligence before initiation of formal negotiations. 


\subsection{Development of post-formation alliance capabilities}

Managing post-formation dynamics is viewed as central to a firm's capacity to internalize benefit from their alliances (Doz, 1996; Ireland et al., 1998; Wang and Rajagopalan, 2015). We note that post-formation capabilities entail: (a) managing interpersonal relationships with members of partner organizations in the Alliance Team (AMT); (b) managing the relationship with members of own organization, including with those who are operationally involved; and (c) creating evaluation criteria to evaluate each individual alliance on its own as well as in the context to other alliances in the alliance portfolio.

\subsubsection{Capabilities to manage relationships at AMT level}

The importance of the AMT in ensuring the smooth functioning of alliances is acknowledged in the alliance literature (e.g. Ireland et al., 2000; Kale and Singh, 2009; Niesten and Jolink, 2015). The AMT of all the four alliances in our study comprised of four members, with two members representing each partner. Interestingly one of the Directors in Indo-Bio's Board of Directors, BM, was one of the representatives in all the four AMTs. The incumbent Head of R\&D at the time of alliance formation would become the second representative. We also note that that common practice was that the AMTs would have face-to-face meetings once every four months to take stock of developments and preempt any potentially adverse developments. The operational teams (project teams) would meet once every few weeks, essentially to brief each other on their progress. As one of the Senior Project Managers noted, "The formal meetings between the project teams are not regular just because there is nothing we (Indo-Bio) have to do until the molecule is discovered". Overall, within Indo-Bio, the AMT was envisaged as the "the core decision making body", but they would only take "informed decisions" based on the inputs from the members of the operational / project teams. This arrangement was designed to ensure that the views and opinions of those involved at operational level were reflected in the strategic decisions taken by the AMT. However, some respondents claimed that the AMT often overlooked their suggestions in meetings, which they to the organizational culture and hierarchical structure of the organization. Our analysis also unearth lack of accountability of AMT representatives to other senior managers. However, learning from the experience of breakdown of relationship between AMT members of IndoBio and US Bio's and due to the discovery of discrepancies in the contractual agreement, the 
SMC decided that the company's representatives in the respective AMTs must be answerable and accountable to the SMC. They will brief the SMC before and after every AMT meeting.

\subsubsection{Capabilities to manage relationships at operational level}

Faems et al. (2008) highlight how perspectives of operational teams could differ from those of senior managers in a collaborative context. In this respect, managing the relationship between the AMT representative and operational and project team members become critical. The role of the senior project managers in Indo-Bio was to provide "day-to-day leadership" in driving specific co-development projects taking place within the respective alliances. Indo-Bio and its partners followed a standard post-formation routine, "(project teams) interact every month although time and content is not always fixed, particularly during the early stages. Research generally does not move very fast so essentially these meetings were about sharing information, keeping each other in the loop" (Senior Project Manager 1). At an individual level, we found that the experience of leading project teams shaped how project managers led subsequent projects. Given this, individual learning was experiential based, dependent on the nature and quality of interaction with the members of the partner organizations. In most instances the operational managers "learnt (how to handle alliance partners) on the job" (Senior Project Manager 2). Experiential based individual learning was critical in the absence of any alliance specific training and development initiatives in Indo-Bio.

\subsubsection{Capabilities to evaluate alliances or alliance portfolio}

Extant research on alliances has identified some key factors and criteria, namely efficiency, equity, adaptability, and relational quality that underpin evaluation of specific alliances by the partner organizations (Doz, 1996). Notwithstanding emerging research on alliance portfolio (Ozcan and Eisenhardt, 2009), evaluation of individual alliances of an organization in the context of its overall alliance portfolio has not been well explored (Kale and Singh, 2009). We consider ability of an organization to evaluate individual alliances on their own as well as in the context of its portfolio of alliances to constitute a critical element of firm's post-formation alliance capability.

By 2007, Indo-Bio had seven co-development projects in the pipeline. It had also successfully introduced MonoBioInd, its first monoclonal antibody product co-developed with Socialist-Bio, in the Indian market. In this backdrop, the company started to evaluate various products it was co-developing with other partners. The CEO was instrumental in formulating 
product evaluation criteria, which subsequently became the key criteria in evaluating different alliances. According to Senior Project Manager 3, "the CEO emphasized that we should focus on differentiating the products we were developing with our partners. We follow two basic criteria in differentiating the products. Each product should differentiate itself from its nearest competitor either on the basis of affordability or functionality". In other words, evaluation of different products was categorized under two categories: (a) products that could compete with nearest competing products based on price (biosimilar or bio-generic products); and (b) products that could potentially have superior functionality as compared to other available products (novel drugs). The objective for Indo-Bio was to achieve a balance between novel and biosimilar products in the pipeline in such a way that it allowed Indo-Bio to develop and commercialize biosimilar more quickly, creating free cash flow that could be invested in other novel drug development programmes.

\section{DISCUSSION AND CONCLUSION}

We identified two critical gaps in the existing literature on alliance capability. First, the studies offer limited insights into how a firm actually translate its experiences from one or more alliances into developing an encompassing 'alliance-capability' and second, majority of research have only paid attention to this phenomenon in larger and more established companies, predominantly based in the US and Europe, thus neglecting firms from emerging economies. In discussing our findings, we also delineate the contributions of our findings to alliance capability literature.

\subsection{Alliance experience}

Alliance experience, defined as "the lessons learned, as well as the know-how generated through a firm's alliances" (Heimeriks and Duysters, 2007: 29), is considered a key mediator in the development of alliance capability. However, the relationship between alliance experience, alliance capability and alliance performance is either conceptualized as a linear relationship (e.g. Anand and Khanna, 2000; Kale et al., 2002) or curvilinear (e.g. Hoang and Rothaermel, 2005; Sampson, 2005). Even those who acknowledge the processual nature of alliance capability development (e.g. Heimeriks and Duysters 2007) do not provide an adequate explanation on how, in practice, firms translate their alliance experiences into alliance capabilities. Our findings provide some valuable insights, particularly relating to areas where 
Indo-Bio succeeded in converting its experiences into concrete processes and routines, which are considered as the building blocks of organizational capabilities, including alliance capabilities (Kale and Singh, 2009) as well as areas where it failed to do so. In this context, our findings, from this EMNE substantiate the extant body of work on alliance capability, which in contrast is primarily based on insights from more established companies.

Recent research on reflective learning, which underpins learning from experiences (Cope, 2003; Lindh and Thorgren, 2015; Howard-Grenville and Rurup, 2016), sensitize us to the significance of critical events in highlighting limitations of existing capabilities, organizational structures and processes. Thus, critical events create conditions for managers to reflection to take corrective measures. Indo-Bio's relationship with US Biol deteriorated because of US Bio1's inability to deliver four functional molecules and subsequent refusal for renegotiation. This experience forced Indo-Bio to critically evaluate its internal structures and processes, particularly on how it forms and manages alliances. Accordingly, Indo-Bio's SMC made numerous suggestions for structural and procedural changes. One of the suggestions, pertained to inclusion of members of the legal department in the negotiation and governance design phase; seeking formal approval of the SMT prior of the contractual terms and agreements before formally signing on the agreement documents and making the AMTs answerable to the SMT. These changes emphasize essence of deliberate learning in action (Zollo and Winter, 2002; Kale and Singh, 2007). Although extant alliance literature highlights the significance of establishing routines between the alliance partners to attain alliance objectives (Zollo et al., 2002; Garcia-Canal et al., 2014), there is less insights on how routines and processes to manage alliances develop within partner firms. Kale and Singh $(2007 ; 2009)$ posits the view that alliance function units in large and established firms located in developed economies, play a critical role in internalizing learning and knowledge from alliances. That said, there is still a gap in knowledge on how and what alliance functioning units succeed in internalizing. In this respect, our research, based on findings from a EMNE makes a significant contribution to alliance capability literature. We specifically highlight how Indo-Bio used experiential learning in evaluating its organizational structure, processes and practices and taking corrective measures, particularly in respect to developing its negotiation and contract design capabilities and post-formational capabilities. Our research also illuminates lack of robust processes to oversee partner selection activities. The unsuccessful attempts to create a dedicated cross-functional unit to undertake due diligence was another illustration wherein 
learning from experience do not necessarily result in concrete actions. Put simply, our findings from this longitudinal study of alliance capability development in Indo Bio, suggest that in EMNEs, which are new to international strategic alliances, such an unit may not exist and in its absence, internalizing learning is more challenging. In fact, as we have noted, the very process that underpins creation of such a unit is equally complex.

\subsection{Alliance function unit}

Extant literature on alliance capabilities, building on insights from more established companies from Europe and US, strongly suggest that firms having a dedicated alliance function team perform better (Kale et al., 2002; Schreiner et at. 2009; Niesten and Jolink, 2015; Howard et al., 2016; Kotamaki et al., 2018). The specialized alliance function teams perform two important roles, namely (a) they act as the central point in coordination of alliance activities; and (b) they are instrumental in capturing, codifying, communicating and disseminating alliance-related knowledge within the organization. Notwithstanding the significance attached to the alliance function unit, there is less insights on how actually such divisions are created. Our analysis highlights the challenges firms face in creating such specialized units. We note that although Indo-Bio's SMC acknowledged the need for a dedicated alliance function team and for that purpose, the company recruited an experienced individual to head this team. However, this specialized dedicated team could not come together as it was not clear what role it would perform, who would be the members of the team, from which departments the members would be drawn from and where would this team locate in the context of Indo-Bio's organizational structure. Significant opposition came from the R\&D division, where alliance activities resided. Further, our findings on the failure of the organization to create a dedicated cross-functional team is particularly insightful. Extant literature on alliance capability suggest the central role of such units but there is less insights on how exactly the units come about at the first place. Considering the critical role that alliance management units play, it is imperative that more studies need to focus on the creation and functioning of these important organizational units.

\subsection{Role of senior managers}

The role of the senior managers is also an area that has attracted limited attention in the extant alliance capability literature (see Kale and Singh, 2009). Emerging studies on Indian business firms shed light on the role of senior managers, particularly founders and owners, in influencing 
critical strategic decisions particularly relating to internationalization of the firms (Purkayastha et al., 2018; Chari, 2013; Chauhan et al., 2016). These findings correspond to insights developed in research on organizational capabilities particularly that explores dynamic capabilities, which posit that senior managers play a central role in sensing and seizing new strategic opportunities and orchestrating necessary organizational complementarities (Eisenhardt and Martin, 2000; Zollo and Winter, 2002; Zahra et al., 2006; Teece, 2014; Pereira et al., 2018; Chikanov et al., 2019) . Our research on Indo-Bio the captures the central role of the founder in alliance formation process. Interestingly, the founder did not play a key role in negotiation and initiation, instead delegated that role to the Heads of $R \& D$, who by virtue of their position became the company's representative in the respective AMT. As a result, the Head of R\&D was prominent actor, next to the founder in terms of their prominence. This was particularly the case in respect to the previous Head of R\&D, who was as the central figure, led the negotiation and drafting of the contractual agreements. However, deterioration of the relationship with US Bio 1 provided an opportunity to the SMT to curb the powers of the Head of R\&D and make them answerable to the SMT. We would argue that role of different managers is a distinctive facet of alliance capability in EMNEs, particularly due to ownership structure of firms, organizational culture and history. The interplay of roles between owners / founders and their managers underpin the development of alliance capability development in EMNEs.

\subsection{Managerial implications}

A recognizable pattern of activities that permits repeatable and reliability is the most distinctive feature of organizational capabilities (Helfat and Peteraf, 2003). According to Kale and Singh (2009) development of alliance capability is a slow and long drawn iterative process. Development of such capabilities need, at the minimum sponsorship and consistent support of senior management team and evaluation and creation of organizational structures and processes. Central to develop alliance capabilities, particularly in non-established organisations, is an organisational culture that encourages sharing of knowledge and experiences and convert individually held tacit know how into reliable routines and processes.

\section{Conclusion}

Our study provides a relatively rare glimpse into the key issues underpinning development of alliance capabilities. In studying a rapidly growing Indian biopharmaceutical company, we 
adopted longitudinal processual approach (Pettigrew 1997; Doz, 2011; Patnaik, 2011; Kohtamaki et al., 2018) and focused our attention on the initial four international alliances Indo-Bio established to develop understanding of what elements the company learnt (or did not) and how it internalized within its own structures and processes. Our research makes three critical contribution to alliance capability research. First, we find evidence that alliance capability is not a linear process rather translating learning from alliance experience is fundamentally challenging as it may lead to questioning existing organisational decisionmaking structures and processes. Thus, having experience in participating in multiple alliances and learning from experiences, do not necessarily lead to alliance capabilities, as it is claimed in extant alliance capability literature (Heimeriks and Duysters, 2007; Kale and Singh, 2007). Second, extant studies based on insights from established and large firms located in developed economies suggest the significance of a dedicated alliance function unit in the development of alliance capability (Kale and Singh, 2009; Schreiner et al., 2009; Kohtamaki et al., 2018). Our research highlight that, unlike in large established companies, creation of a dedicated alliance function unit, particularly in EMNEs, which are primarily family owned organizations, is a complex and challenging process, particularly when the senior management influences alliance formation decisions making processes. Third, we bring to forth the role of senior managers in creating conditions for alliance capability development, an area that has attracted limited attention in the literature, but is critical in context to alliance capability development in EMNEs.

\section{REFERENCES}

1. Altinay, L., \& Brookes, M. (2012). Factors influencing relationship development in franchise partnerships. Journal of Services Marketing, 26(4), 278-292.

2. Altinay, L., Brookes, M., Yeung, R., \& Aktas, G. (2014a). Franchisees' perceptions of relationship development in franchise partnerships. Journal of Services Marketing, 28(6), 509-519.

3. Altinay, L., Brookes, M., Madanoglu, M., \& Aktas, G. (2014b). Franchisees' trust in and satisfaction with franchise partnerships. Journal of Business Research, 67(5), 722728. 
4. Altinay, L., Saunders, M. N., \& Wang, C. L. (2014c). The influence of culture on trust judgments in customer relationship development by ethnic minority small businesses. Journal of Small Business Management, 52(1), 59-78.

5. Anand, B., \& Khanna, T. (2000). Do Firms Learn to Create Value? The Case of Alliances. Strategic Management Journal, 21(3), 295-315.

6. Argyres, N. S. and Mayer, K. J. (2007). Contract design as firm capability: An integration of learning and transaction cost perspectives. Academy of Management Review. 32(4): 1060-1077.

7. Athreye, S., Kale, D. and Ramani, S.V. (2009). Experimentation with strategy and the evolution of dynamic capability in the Indian pharmaceutical sector. Industrial and Corporate Change. 18 (4): 729-759.

8. Beamish, P. W., \& Lupton, N. C. (2016). Cooperative strategies in international business and management: Reflections on the past 50 years and future directions. Journal of World Business, 51(1), 163-175.

9. Brookes, M., \& Altinay, L. (2017). Knowledge transfer and isomorphism in franchise networks. International Journal of Hospitality Management, 62, 33-42.

10. Chichkanov, N., Miles, I \& Belousova, V. (2019). Drivers for innovation in KIBS: evidence from Russia, The Service Industries Journal. DOI: $\underline{10.1080 / 02642069.2019 .1570151}$

11. Chittoor, R., Sarkar, M.B., Ray, S. and Aulakh, P.S. (2009). Third-world copycats to Emerging Multinationals: Institutional changes and organizational transformation in the Indian Pharmaceutical industry. Organization Science, 20 (1): 187-205.

12. Contractor, F. J. (2005). Alliance structure and process: will the two research streams ever meet in alliance research? European Management Review, 2(2), 123-129.

13. Cope, J. (2003). Entrepreneurial learning and critical reflection: Discontinuous events as triggers for 'higher-level' learning. Management Learning 34 (4): 429-450.

14. Doz, Y. L. (1996). The evolution of cooperation in strategic alliances: Initial conditions or learning processes?. Strategic management journal, 17(S1), 55-83.

15. Doz, Y. (2011). Qualitative Research in International Business. Journal of International Business Studies, Vol. 42(5), 582-590.

16. Eisenhardt, K. M., \& Martin, J. A. (2000). Dynamic capabilities: what are they?. Strategic management journal, 21(10-11), 1105-1121.

17. Eisenhardt, K.M. and Graebner, M.E., 2007. Theory building from cases: Opportunities and challenges. The Academy of Management Journal, 50(1), pp.25-32. 
18. Faems, D., Janssens, M., Madhok, A. and Van Looy, B. (2008). Toward an integrative perspective on alliance governance: Connecting contract design, trust dynamics, and contract application. Academy of Management Journal, 51(6): 1053-1078.

19. Goerzen, A. (2007). Alliance networks and firm performance: The impact of repeated ties. Strategic Management Journal, 28(5): 487-509.

20. Gulati, R. (1998). Alliances and networks. Strategic Management Journal, 19(4): 293317.

21. Gulati, R. and Singh, H. (1998). The architecture of cooperation: Managing coordination costs and appropriation concerns in strategic alliances. Administrative Science Quarterly, 43(4): 781-814.

22. Gulati, R., Lavie, D.and Singh, H. (2009). The nature of partnering experience and the gains from alliances. Strategic Management Journal, 30(11): 1213-1233.

23. Heimeriks, K.H. and Duysters, G (2007). Alliance capability as a mediator between experience and alliance performance: An empirical investigation into alliance capability development process. Journal of Management Studies, 44(1): 25-49.

24. Hoang, H., \& Rothaermel, F. T. (2005). The effect of general and partner-specific alliance experience on joint R\&D project performance. Academy of Management Journal, 48(2), 332-345.

25. Howard, M., Steensma, K.H., Lyles, M.and Dhanaraj, C. 2016. Learning to collaborate through collaboration: How allying with expert firms influences collaborative innovation within novice firms. Strategic Management Journal, 37(10): 2092-2103.

26. Ireland, R. D., Hitt, M.A. and Vaidyanath, D. (2002). Alliance management as a source of competitive advantage. Journal of Management, 28(3): 413-446.

27. Kale, D. (2012). Innovative capability development in the Indian pharmaceutical industry. International Journal of Innovation and Technology Management, 9(02), 1250013.

28. Kale, P., Dyer, J.H. and Singh, H. (2002). Alliance capability, stock market response, and long term alliance success: The role of the alliance function. Strategic Management Journal, 23: 747-767.

29. Kale, P. and Singh. H. (2007). Building firm capabilities through learning: The Role of the alliance learning process in alliance capability and firm-level alliance success. Strategic Management Journal, 28(10): 981-1000. 
30. Kaupilla, O.P. (2015). Alliance Management Capability and Firm Performance: Using Resource-based Theory to Look Inside the Process Black Box, Long Range Planning, 48 (3): 151-167.

31. Kohtamaki, M., Rabetino, R., Moller, K. (2018). Alliance capabilities: A review and research agenda. Industrial Marketing Management, 68:188-201.

32. Lumineau, F., Frechet, M. and Puthod, D. (2011). An organizational learning perspective on the contracting process. Strategic Organization, 9(1): 8-32.

33. Kale, P. and Singh, H. (2009). Managing strategic alliances: what do we know now, and where do we go from here? Academy of Management Perspectives, 23(3), 45-62.

34. Patnaik, S. 2011. Inter-organisational collaborations as embedded social systems : a critical realist explanation of alliance evolution. Unpublished Doctoral Thesis, University of Liverpool

35. Patnaik, S., Pereira, V., Temouri, Y., Malik, A., \& Roohanifar, M. 2020. The dance of power and trust-exploring micro-foundational dimensions in the development of global health partnership. Technological Forecasting and Social Change, 156 (in-press).

36. Pereira, V., Mellahi, K., Temouri, Y., Patnaik, S., \& Roohanifar, M. (2018). Investigating dynamic capabilities, agility and knowledge management within EMNEslongitudinal evidence from Europe. Journal of Knowledge Management._23 (9), 17081728.

37. Pereira, V., Temouri, Y., Patnaik, S., Mellahi, K. (2020) Managing and Preparing for Emerging Infectious Diseases - Avoiding a Catastrophe. Academy of Management Perspective (in press).

38. Pettigrew, A. (1990). Longitudinal Field Research on Change Theory \& Practise. Organization Science, 1(3), 267-292.

39. Pettigrew, A. (1997). What is processual analysis? Scandinavian Journal of Management, 13 (4), 337-348.

40. Purkayastha, S., Manolava, T.S., and Feldman, L.F. (2018). Business group effects on the $R \& D$ intensity-internationalization relationship: Empirical evidence from India. Journal of World Business, 53 (2): 104-117.

41. Reuer, J. J., Zollo, M., \& Singh, H. (2002). Post - formation dynamics in strategic alliances. Strategic Management Journal, 23(2), 135-151. 
42. Schreiner, M., Kale, P., \& Corsten, D. (2009). What really is alliance management capability and how does it impact alliance outcomes and success? Strategic Management Journal, 30(13), 1395-1419.

43. Shah, R. H. and Swaminathan, V (2008). Factors influencing partner selection in strategic alliances: the moderating role of alliance context. Strategic Management Journal, 29(5): 471-494.

44. Siggelkow, N., 2007. Persuasion with case studies. Academy of management journal, 50(1), pp.20-24.

45. Teece, D. J. (2014). The foundations of enterprise performance: Dynamic and ordinary capabilities in an (economic) theory of firms. Academy of management perspectives, 28(4), 328-352.

46. Teece, D. J., Pissano, G. and Shuen, A (1997). Dynamic capabilities and strategic management. Strategic Management Journal, 18(7): 509-533.

47. Yin, R. K. (1994). Case Study Research: Design and Methods. Thousand Oaks, Sage Publications.

48. Wang, Y., \& Rajagopalan, N. (2015). Alliance capabilities: review and research agenda. Journal of management, 41(1), 236-260.

49. Zahra, S. A., Sapienza, H. J., \& Davidsson, P. (2006). Entrepreneurship and dynamic capabilities: A review, model and research agenda. Journal of Management studies, 43(4), 917-955.

50. Zollo, M., Reuer, J. J., \& Singh, H. (2002). Interorganizational routines and performance in strategic alliances. Organization science, 13(6), 701-713.

51. Zollo, M., \& Winter, S. G. (2002). Deliberate learning and the evolution of dynamic capabilities. Organization science, 13(3), 339-351.

52. Yin, R. K. (2017). Case study research and applications: Design and methods. Sage publications. 
Table 1: Brief descriptions of Indo-Bio's four co-product development alliances

\begin{tabular}{|c|c|c|c|c|}
\hline & Socialist-Bio & US Bio1 & US-Bio2 & US-Bio3 \\
\hline $\begin{array}{l}\text { Brief description } \\
\text { of the partners }\end{array}$ & $\begin{array}{l}\text { Socialist-Bio is the } \\
\text { comme ial arm of } \\
\text { a soc'dl st } \\
\text { country s ese a }{ }^{\text {ch }} \\
\text { center. }\end{array}$ & $\begin{array}{l}\text { US Biol is a privately held } \\
\text { biotechnology company } \\
\text { based in the US. It is } \\
\text { engaged in the discovery } \\
\text { and development of novel } \\
\text { trirapeutic antibodies }\end{array}$ & $\begin{array}{l}\text { US-Bio } 2 \text { was a small US } \\
\text { based research company, } \\
\text { which had developed a } \\
\text { proprietary technology to } \\
\text { enable oral delivery of } \\
\text { protein, peptide and small } \\
\text { molecule drugs. } \\
\text { The company went } \\
\text { bankrupt in } 2008 \text {. }\end{array}$ & $\begin{array}{l}\text { US-Bio3 is a privately } \\
\text { held biotechnology } \\
\text { company engaged in the } \\
\text { discovery and } \\
\text { development of novel } \\
\text { immunoconjugates for the } \\
\text { treatment of cancer and } \\
\text { infectious disorders. }\end{array}$ \\
\hline $\begin{array}{l}\text { Alliance } \\
\text { formation }\end{array}$ & 2003 & 2004 & 2004 & 2008 \\
\hline
\end{tabular}




\begin{tabular}{|c|c|c|c|c|}
\hline $\begin{array}{l}\text { Purpose of the } \\
\text { alliance }\end{array}$ & $\begin{array}{l}\text { Commercialization } \\
\text { of pre-existing } \\
\text { products of } \\
\text { Socialist-Bio in } \\
\text { India and } \\
\text { Co-development } \\
\text { of new c rugs for } \\
\text { the tiea r.er.t of } \\
\text { different f J rms of } \\
\text { cancer }\end{array}$ & $\begin{array}{l}\text { Discovery and co- } \\
\text { development of four fully } \\
\text { humanized antibodies for } \\
\text { the treatment of focused on } \\
\text { cancer, inflammation and } \\
\text { autoimmune diseases }\end{array}$ & $\begin{array}{l}\text { Co-development and } \\
\text { commercialization of oral } \\
\text { insulin. }\end{array}$ & $\begin{array}{l}\text { Discovery and co- } \\
\text { development of an } \\
\text { exclusive new class of } \\
\text { immunoconjugates for } \\
\text { targeted immunotherapy } \\
\text { of cancers and infectious } \\
\text { diseases }\end{array}$ \\
\hline $\begin{array}{l}\text { Governance } \\
\text { mechanism of the } \\
\text { alliance }\end{array}$ & $\begin{array}{l}\text { Joint venture } \\
\text { (Indo-Bio 51\% - } \\
\text { Socialist-Bio 49\%) }\end{array}$ & $\begin{array}{l}\text { Entractual partnership } \\
\text { att ous i Indo-Bio made a } \\
\text { minu it o dity investment }\end{array}$ & Contractual partnership & $\begin{array}{l}\text { Contractual partnership } \\
\text { although Indo-Bio made a } \\
\text { minority equity } \\
\text { investment. }\end{array}$ \\
\hline Key highlight(s) & $\begin{array}{l}\text { Indo-Bio acquires } \\
\text { the stake of } \\
\text { Socialist-Bio in } \\
\text { the joint venture } \\
\text { and enters into a } \\
\text { long-term research } \\
\text { partnership with } \\
\text { its parent research } \\
\text { center }\end{array}$ & $\begin{array}{l}\text { Only one out of initially } \\
\text { planned four co- } \\
\text { development programmes } \\
\text { was under development. } \\
\text { The relationship suffered } \\
\text { due to trust issues and the } \\
\text { two partners decided not to } \\
\text { extend the relationship } \\
\text { further. }\end{array}$ & $\begin{array}{l}\text { Indo-Bio successfully bid } \\
\text { for and acquired US-Bio } \\
\text { assets to develop oral } \\
\text { insulin on its own after the } \\
\text { partner filed for bankruptcy } \\
\text { in } 2008\end{array}$ & $\begin{array}{l}\text { The partners had identified } \\
\text { two molecules for co- } \\
\text { development }\end{array}$ \\
\hline
\end{tabular}


Table 2: List of interviewees / respondents

\begin{tabular}{|c|c|c|}
\hline $\begin{array}{l}\text { Designation of the } \\
\text { interviewees }\end{array}$ & Profile of the interviewee and the nature of the interviews & $\begin{array}{l}\text { Number of times } \\
\text { interviewed (No of hrs) }\end{array}$ \\
\hline Head of R\&D & $\begin{array}{l}\text { Overview of the broad strategy of Indo-Bio including focus on new } \\
\text { therape ic areas as well as an overview on each of the four strategic } \\
\text { alliar.s. } s \text {, the Head of R\&D, the individual was directly involved in } \\
\text { overseein', the sperational }\end{array}$ & $2(4 \mathrm{hrs})$ \\
\hline Head of Legal Team & Legal and contidet al in sues relating to all alliances. & $1(2 \mathrm{hr})$ \\
\hline Member of BOD, SMC & $\begin{array}{l}\text { He was the previous heau of } 2 \& \Gamma \text { ad was one of the members of Alliance } \\
\text { Management Committee oversee ing inr o-Bio's alliances with Socialist-Bio, } \\
\text { US Bio1 and US-BIO2. }\end{array}$ & $1(2 \mathrm{hr})$ \\
\hline $\begin{array}{l}\text { Senior Project Manager } \\
1\end{array}$ & 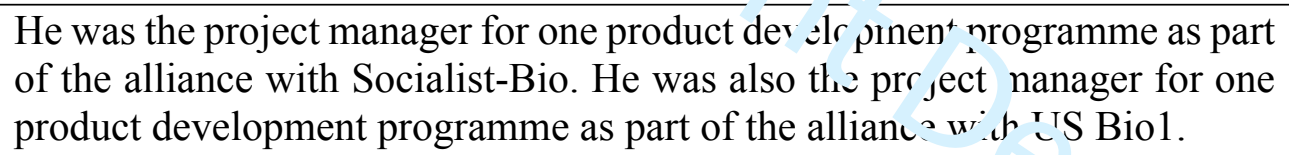 & $3(6 \mathrm{hrs})$ \\
\hline $\begin{array}{l}\text { Senior Project Manager } \\
2\end{array}$ & $\begin{array}{l}\text { He was the project manager for the second product development programme } \\
\text { as part of the alliance with US Bio1. The project faced severe problems } \\
\text { because of which it was terminated in } 2009 \text {. He subsequently became the } \\
\text { project manager for the development programme relating to US-Bio3. As } \\
\text { his role as the leader of molecular biology group, he had an insight on the } \\
\text { developments in the project relating to Socialist-Bio. }\end{array}$ & $3(5 \mathrm{hrs})$ \\
\hline
\end{tabular}




\begin{tabular}{|l|l|l|}
\hline $\begin{array}{l}\text { Senior Project Manager } \\
3\end{array}$ & $\begin{array}{l}\text { He had been heading developing of a new drug (Oral insulin) being } \\
\text { developed with US-BIO2. In 2006-07, Indo-Bio acquired IP relating to the } \\
\text { oral insulin when US-BIO2 filed for bankruptcy. }\end{array}$ & $1(2 \mathrm{hrs})$ \\
\hline $\begin{array}{l}\text { Group leader } \\
\text { Fermentation }\end{array}$ & $\begin{array}{l}\text { In his role as a group leader, he had insights on all the products under } \\
\text { development including those relating to US Bio1 and Socialist-Bio. }\end{array}$ & $1(2 \mathrm{hrs})$ \\
\hline $\begin{array}{l}\text { Group leader - Protein } \\
\text { Purification }\end{array}$ & $\begin{array}{l}\text { In her role as the group leader, she too had insights on all the products } \\
\text { under development. }\end{array}$ & $1(2 \mathrm{hrs})$ \\
\hline & & $\begin{array}{l}\text { Approximately } 25 \text { hrs of } \\
\text { interviews }\end{array}$ \\
\hline
\end{tabular}


Figure 1: Overlapping phases in alliance development process and key activities

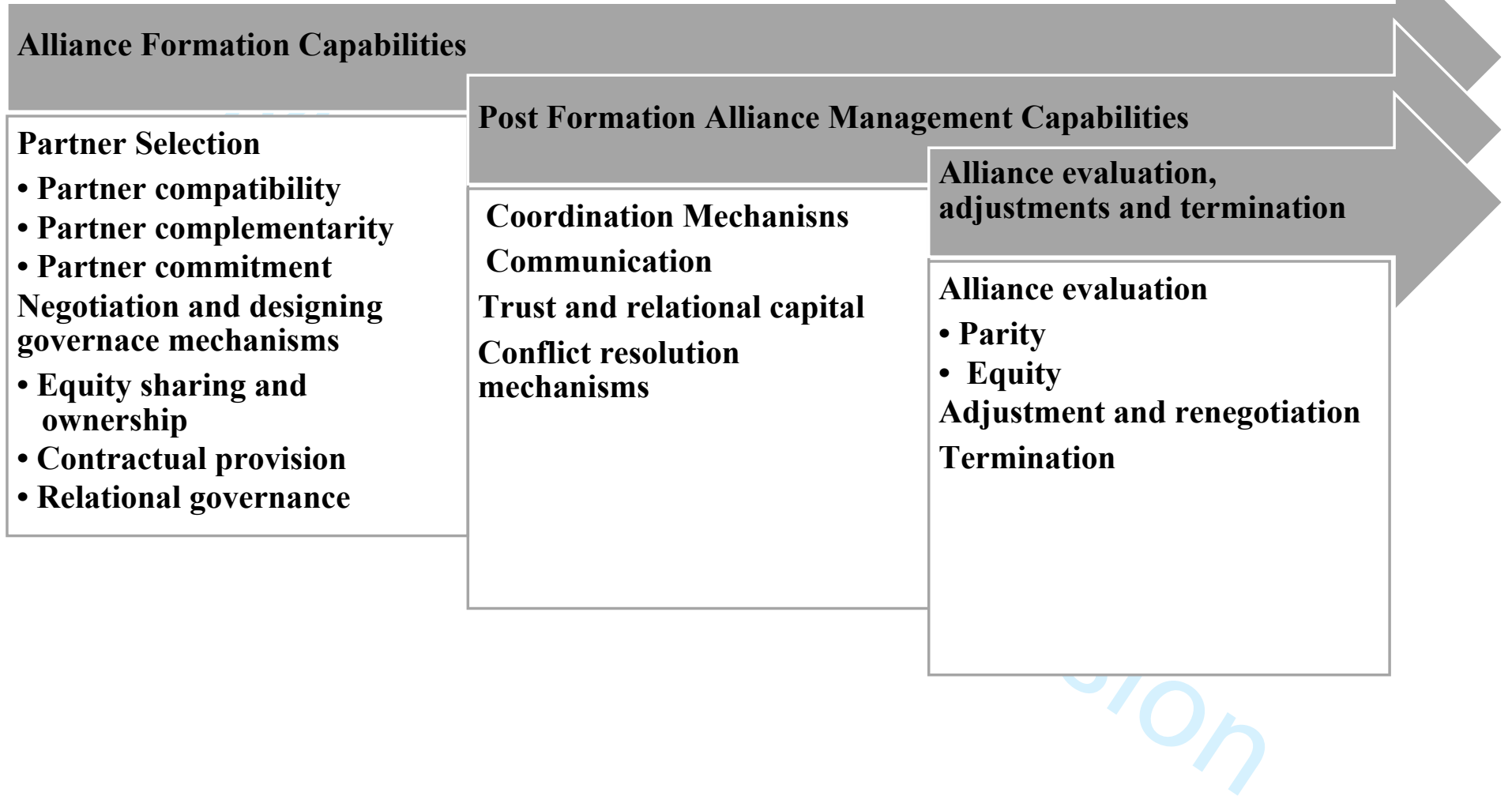




\section{Figure 2: Historical evolution of Indo-Bio}

Indo-Bio becomes amongst the first Indian companies to manufacture enzymes for the beverages industry. It scales up its in-house research programme, based on a proprietary solid substrate fermentation technology, from pilot to plant level
Indo-Bio sets up a subsidiary custom research company to cater to the growing need for outsourced $R \& D$ in the pharmaceutical sector. It leverages its technology platform to manufacture biopharmaceuticals and statins and sets up a dedicated manufacturing facility. The company establishes a clinical research organization to pursue clinical research and development. It receives US FDA approval for manufacturing a cholesterol-lowering molecule.

Becomes one of the few companies worldwide to develop human insulin on a specific (Pichia) expression system
Indo-Bio forms a joint venture with SocialistBio to manufacture and market a range of bio-pharmaceutical products already developed by Socialist-Bio. The alliance allowed Indo-Bio to move into the monoclonal antibody segment. Indo-Bio goes public with a hugely successful IPO. It also forms an alliance with US-Bio1 to discover and co-develop therapeutic products. IndoBio forms an alliance with US-Bio2US- to co-develop oral insulin

Indo-Bio forms an alliance with US-Bio3 to co-develop new class of immunoconjugates for targeted immunotherapy of cancers and infectious diseases 


\section{Figure 3: Indo-Bio's initial co-occurring international strategic alliances}

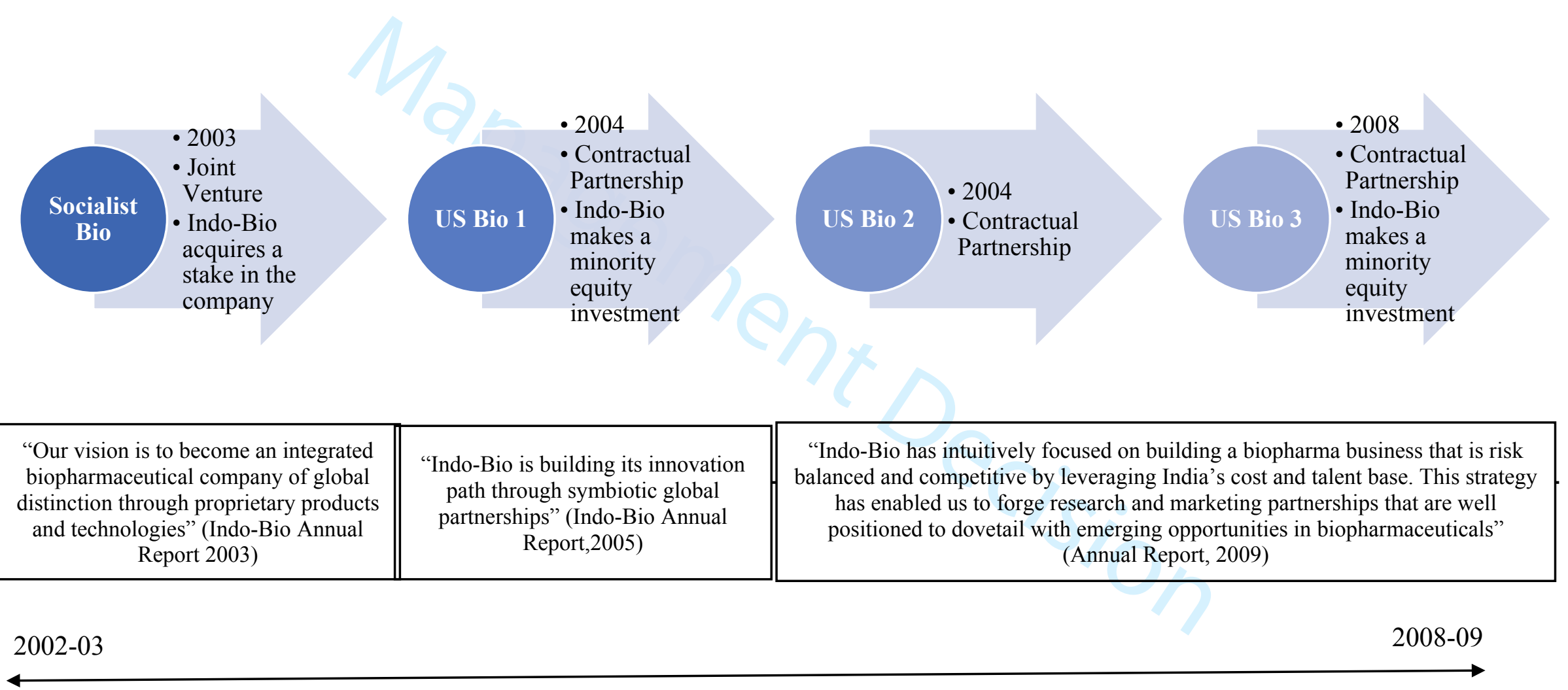


Figure 4 - Data structure

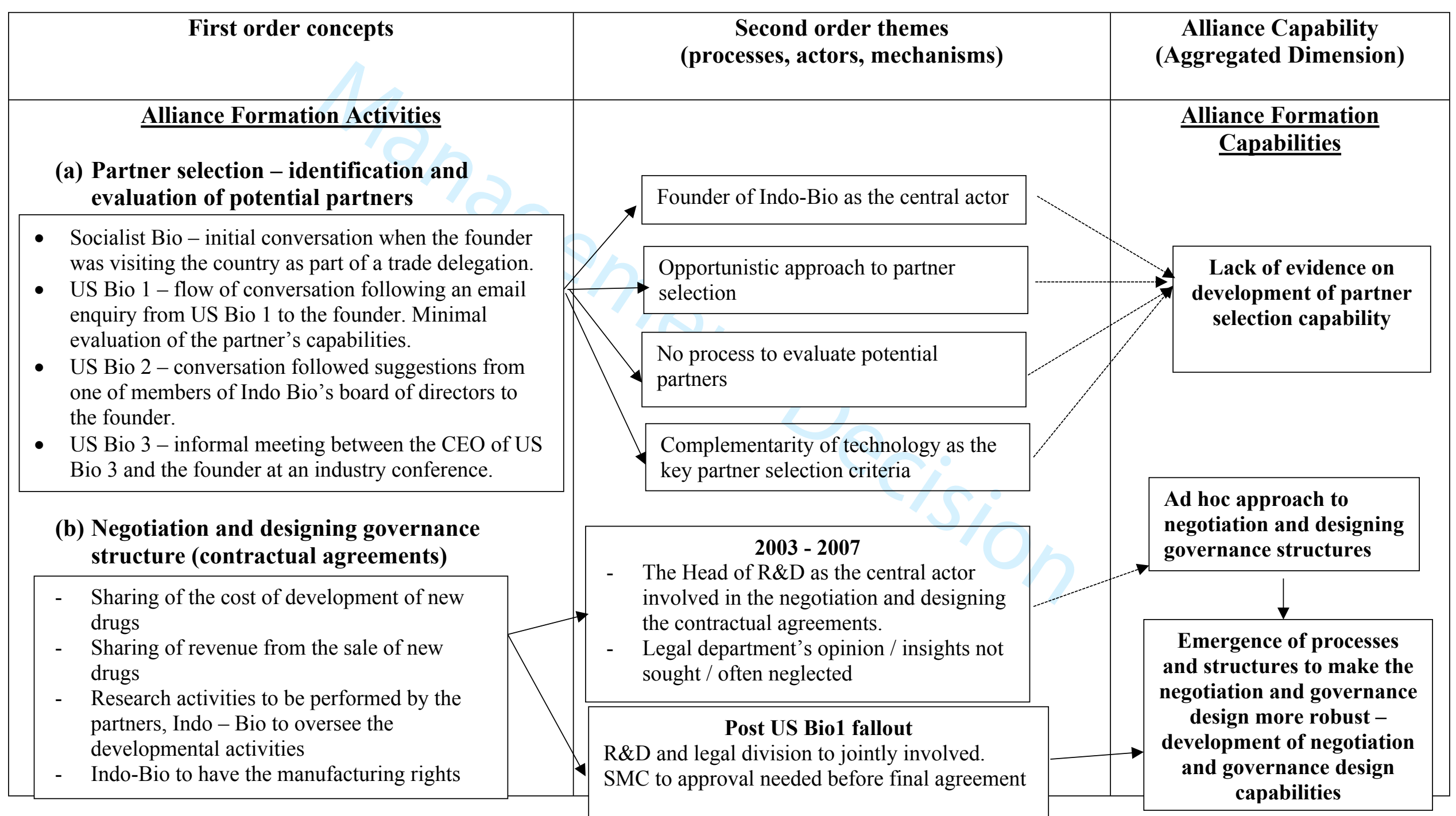




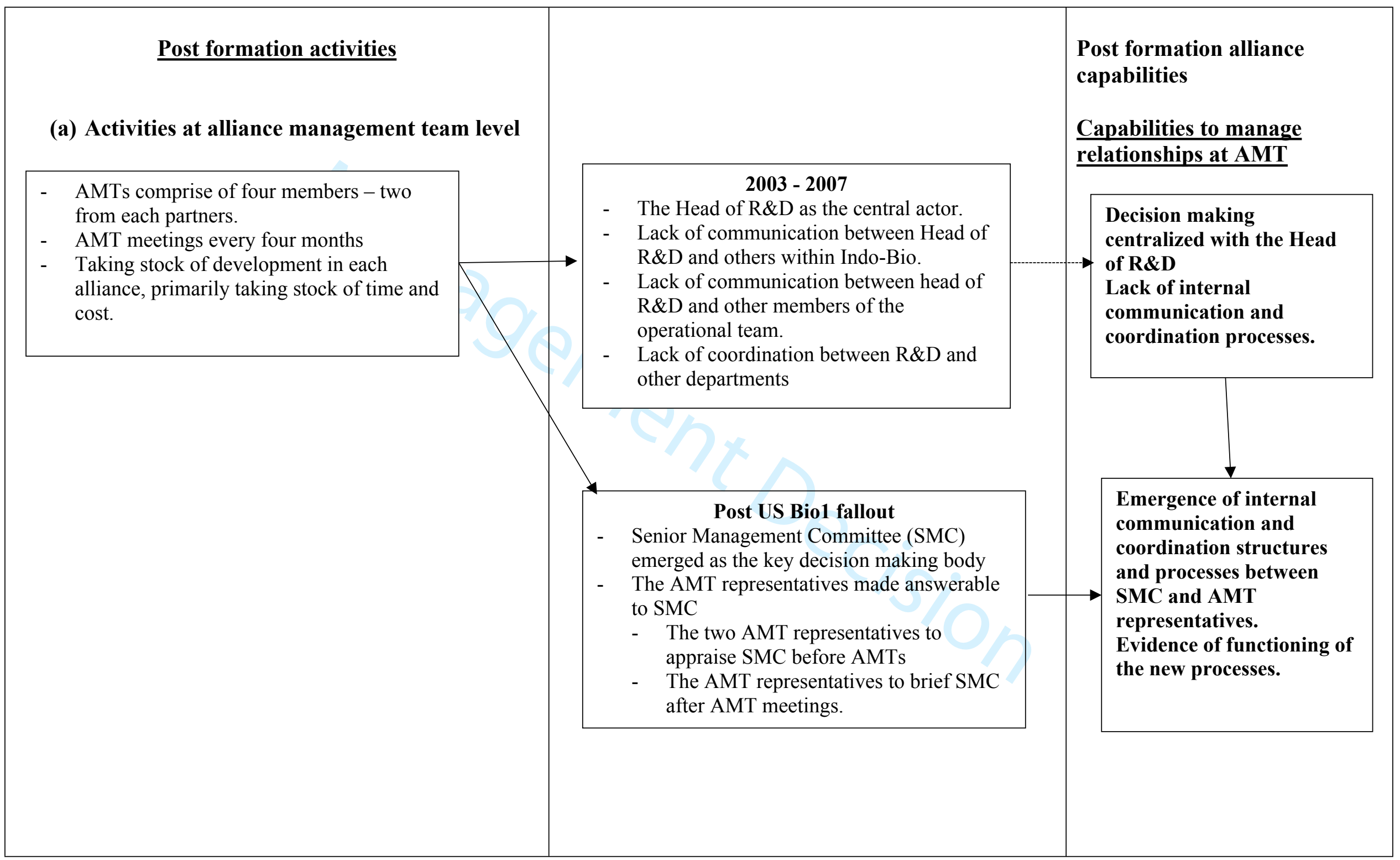




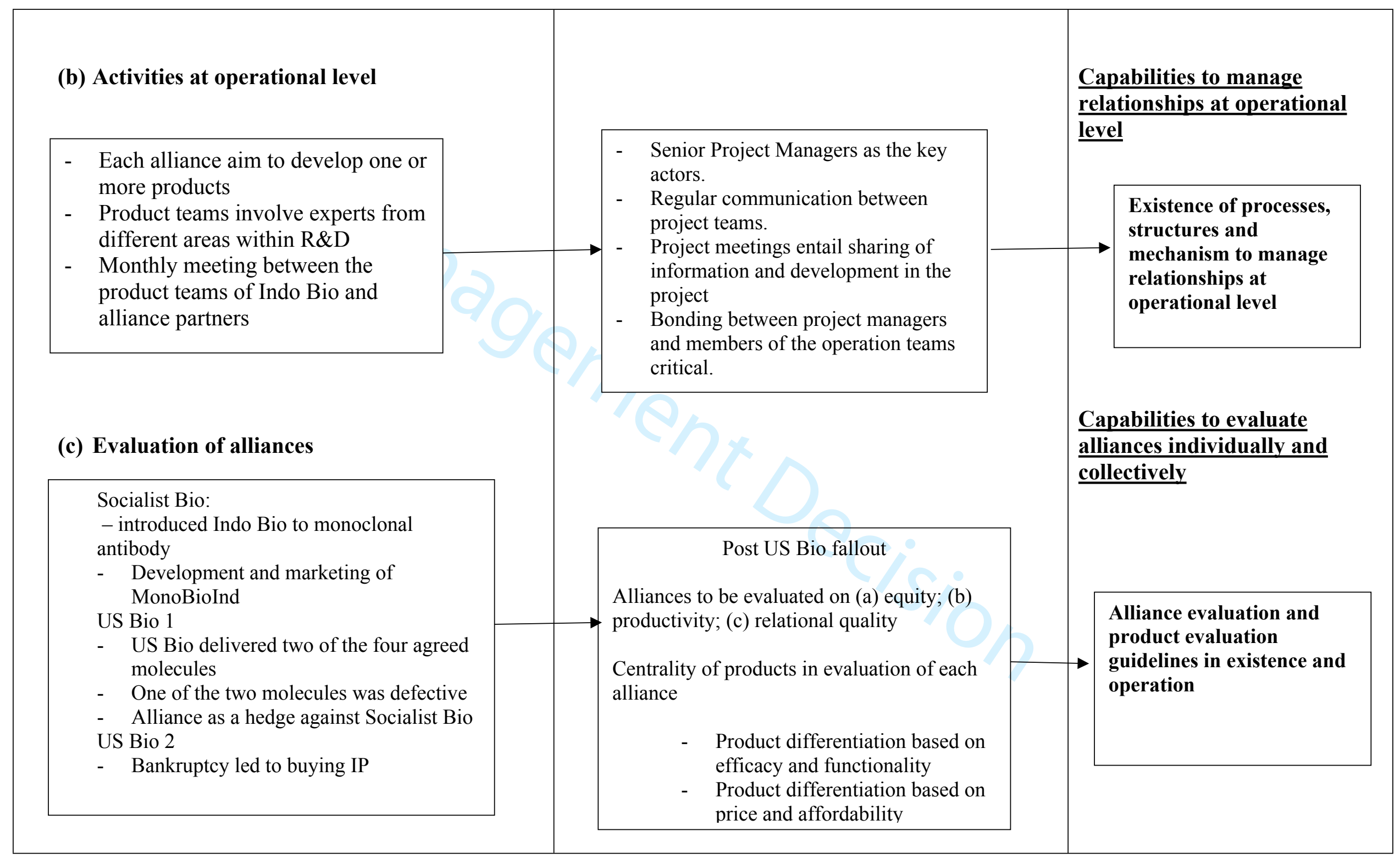

